\title{
A comparison of the in vitro activity of metronidazole, tinidazole, and nimorazole against Gram-negative anaerobic bacilli
}

\author{
A. V. REYNOLDS, J. M. T. HAMILTON-MILLER, AND W. BRUMFITT \\ From the Royal Free Hospital, Department of Medical Microbiology, Pond Street, Hampstead, \\ London NW3 2QG
}

SYNOPSIS The in vitro activities of metronidazole, nimorazole, and tinidazole were compared against 69 strains of obligately anaerobic Gram-negative bacilli. Geometric mean MICs were $0 \cdot 34$, 1.05 , and $0.28 \mu \mathrm{g} / \mathrm{ml}$ respectively. Thirty-six strains were also tested by the disk method. Correlation between MIC and diameter of the zones of inhibition was poor.

Metronidazole (1- $\beta$-hydroxymethyl-2-methyl-5nitroimidazole, Flagyl, May \& Baker) is at present the drug used most widely for the treatment of Trichomonas vaginalis infection. It is of interest that it has also been effective in the treatment of acute ulcerative gingivitis (Shinn, 1962; Davies et al, 1964; Shinn et al, 1965), an infection in which anaerobic bacteria (Treponema vincentii and Fusobacterium spp.) are believed to have an aetiological rôle. Recent studies have shown that all the clinically important species of anaerobic bacteria are sensitive to therapeutically attainable concentrations of metronidazole (Füzi and Csukas, 1969a, b, c, 1970; Prince et al, 1969; Ueno et al, 1971; Videau, 1971; Nastro and Finegold, 1972; Tally et al, 1972, 1974; Finegold and Sutter, 1972; Whelan and Hale, 1973; Mitchell, 1973; Washington et al, 1974; Dornbusch and Nord, 1974; Phillips, 1974; Staneck and Washington, 1974). In addition, metronidazole is consistently bactericidal in action, which is a property not shown by clindamycin, rifampicin or chloramphenicol (Nastro and Finegold, 1972; Finegold and Sutter, 1972; Whelan and Hale, 1973). Two reports have appeared on the clinical use of metronidazole: Tally et al (1972) successfully treated three patients with infections caused by Gramnegative anaerobic bacteria, and the Study Group (1974) showed that metronidazole was effective both therapeutically and prophylactically in gynaecological patients with pelvic sepsis.

Nimorazole $^{1} \quad(1-(\mathrm{N}-\beta$-ethylmorpholino)-5-nitro-

${ }^{1}$ Previously known as nitrimidazine.

Received for publication 14 April 1975. imidazole, Nagoxin, Carlo Erba) and tinidazole (1 (2-ethylsulphonylethyl)-2-methyl-5-nitroimidazole Fasigyn, Pfizer) are also 5-nitroimidazoles whose antitrichomonal activity in vitro is similar to that of metronidazole (de Carneri et al, 1969; Howes et al, 1970). Both have been used successfully to treat trichomoniasis, with reduction in both daily doses and treatment period compared with metronidazole (Rognoni and Sideri, 1969; Györik and Wenner, 1971). Nimorazole was also found to be as effective as metronidazole in the treatment of acute ulcerative gingivitis (Lozdan et al, 1971). Considering the superior pharmacokinetic properties of nimorazole and tinidazole, we thought it worthwhile to carry out a comparison of the in vitro activity of these three 5-nitroimidazoles against Gram-negative anaerobic bacteria.

\section{Methods and Materials}

\section{5-NITROIMIDAZOLES}

Pure samples of metronidazole, nimorazole, and tinidazole were supplied by May \& Baker, Carlo Erba, and Pfizer, respectively.

\section{BACTERIAL STRAINS}

Sixty-nine strains were studied: all were obligately anaerobic Gram-negative rods. Twenty-four strains (8 Fusobacterium spp. and 16 Bacteroides fragilis) were either reference strains (from the National Collection of Type Cultures, London or Center for Disease Control, Ga, USA) or identified clinical isolates from other hospitals. The majority of the remaining 45 strains had been isolated from clinical 
material from the Royal Free Hospital but some were kindly donated by other hospitals. We provisionally identified 43 of these as $B$. fragilis, since they were resistant to polymyxin $B(10 \mu \mathrm{g} / \mathrm{ml})$, kanamycin $(2 \mathrm{mg} / \mathrm{ml})$, and benzylpenicillin $(2 \mathrm{u} / \mathrm{ml})$ (Finegold et al, 1967). The other two strains were sensitive to benzylpenicillin and thus were classified as Bacteroides spp.

\section{MIC DETERMINATION}

Throughout these experiments, media were supplemented with yeast extract $(1 \%)$, haemin $(5 \mu \mathrm{g} / \mathrm{ml})$, and menadione $(0.5 \mu \mathrm{g} / \mathrm{ml})$.

Serial doubling dilutions of the drugs were made in brain heart infusion agar (Oxoid, CM 375) containing $5 \%$ lysed, defibrinated horse blood. Bacteria were grown in $10 \mathrm{ml}$ amounts of thioglycollate broth (Baltimore Biological Laboratories, no. 135C) incubated anaerobically at $37^{\circ} \mathrm{C}$ for $22 \mathrm{hr}$, using the GasPak system. Such cultures were diluted 1:500 in sterile $0.06 \mathrm{M}$ sodium phosphate buffer containing $0.3 \mathrm{~g} / 1$ cysteine hydrochloride, and inoculated on to the agar with a multiple inoculating device (see Reynolds et al, 1974). Plates were incubated at $37^{\circ} \mathrm{C}$ for $42 \mathrm{hr}$ using the GasPak system. Control plates containing no antibiotic were inoculated and incubated both aerobically and anaerobically. MIC was taken as the lowest drug concentration that completely inhibited growth or allowed the development of no more than two discrete colonies; such a finding is evidence of at least $99.95 \%$ inhibition.

\section{Disk Diffusion Tests}

Broth cultures were grown as above and diluted 1:50 in buffer. Fifteen millilitre amounts of supplemented (see above) brain heart infusion agar $+5 \%$ whole horse blood in $9 \mathrm{~cm}$ plates were flooded with the diluted cultures and excess fluid was removed. Disks containing $2.5 \mu \mathrm{g}$ of drug were prepared by dipping $6 \mathrm{~mm}$ AA disks (Whatman) into solutions of each individual drug which contained $125 \mu \mathrm{g} / \mathrm{ml}$. These were then placed on to the surface of the agar. Only one disk was put on to each plate. Plates were incubated anaerobically using the GasPak system for $18 \mathrm{hr}$ at $37^{\circ} \mathrm{C}$, and zones of inhibition were measured with calipers.

\section{Analysis of Data}

Graphs were constructed to compare zone size with MIC for each compound; in addition, results for all three compounds were combined onto a single plot. Analysis was as described by Ericsson and Sherris (1971).

\section{Results}

As can be seen from table I, there was no clear

\begin{tabular}{|c|c|c|c|c|c|c|c|c|}
\hline & \multicolumn{8}{|c|}{$M I C(\mu g / m l)$} \\
\hline & 0.062 & 0.125 & 0.25 & 0.5 & $1 \cdot 0$ & $2 \cdot 0$ & $4 \cdot 0$ & $8 \cdot 0$ \\
\hline $\begin{array}{l}\text { Metronidazole } \\
\text { Fusobacterium sp } \\
\text { B. fragilis } \\
\text { Bacteroides sp }\end{array}$ & 1 & $\begin{array}{l}2 \\
3\end{array}$ & $\begin{array}{r}4 \\
27 \\
1\end{array}$ & $\begin{array}{r}24 \\
1\end{array}$ & $\begin{array}{l}1 \\
4\end{array}$ & & 1 & \\
\hline $\begin{array}{l}\text { Nimorazole } \\
\quad \text { Fusobacterium sp } \\
\text { B. fragilis } \\
\text { Bacteroides sp }\end{array}$ & & & 3 & 7 & $\begin{array}{r}2 \\
41 \\
2\end{array}$ & $\begin{array}{l}5 \\
6\end{array}$ & $\begin{array}{l}1 \\
1\end{array}$ & 1 \\
\hline $\begin{array}{l}\text { Tinidazole } \\
\quad \text { Fusobacterium sp } \\
\text { B. fragilis } \\
\text { Bacteroides } \mathbf{s p}\end{array}$ & 2 & $\begin{array}{l}2 \\
7\end{array}$ & $\begin{array}{r}5 \\
31 \\
1\end{array}$ & $\begin{array}{r}1 \\
15 \\
1\end{array}$ & 3 & 1 & & \\
\hline Geometric mean MIC & \multicolumn{8}{|c|}{$\begin{array}{ll}\text { Metronidazole } & 0.34 \mu \mathrm{g} / \mathrm{ml} \\
\text { Nimorazole } & 1.05 \mu \mathrm{g} / \mathrm{ml} \\
\text { Tinidazole } & 0.28 \mu \mathrm{g} / \mathrm{ml}\end{array}$} \\
\hline
\end{tabular}

Table I Activity of metronidazole, nimorazole, and tinidazole against Gram-negative anaerobic bacteria

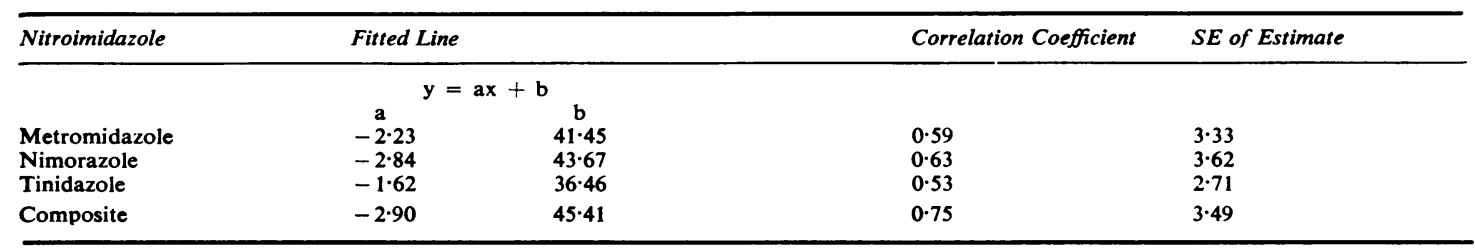

Table II Correlation of MIC to zone diameter 
difference between the sensitivity patterns of Fusobacterium spp and $B$. fragilis; therefore it was considered to be justified to combine data for all strains. Tinidazole was slightly more active than was metronidazole, the two compounds having geometric mean MICs of 0.28 and $0.34 \mu \mathrm{g} / \mathrm{ml}$ respectively. Nimorazole was about threefold less active, having a geometric mean MIC of $1.05 \mu \mathrm{g} / \mathrm{ml}$.

Thirty-six strains were also tested by the disk method, and the results are summarized in table II. To increase the spread of values and thereby make the interpretation of results easier a composite scatter diagram was constructed and a statistical analysis of this is also shown in table II.

\section{Discussion}

A large number of reports over the past few years have shown metronidazole to be highly active against both Gram-positive and Gram-negative anaerobic bacteria (for review see Hamilton-Miller, 1975). Two other nitroimidazoles, nimorazole and tinidazole, are currently available for the treatment of trichomoniasis (although tinidazole is not at present available on prescription in the UK.) We have not seen any reports on the antibacterial activity of nimorazole, and only two concerning tinidazole. Edwards et al (1973) reported that tinidazole was slightly less active than metronidazole against eight strains of Clostridium spp, a conclusion confirmed by Dornbusch and Nord (1974), who also found tinidazole to be more active than metronidazole against Gram-negative organisms. Our results have been extended to include nimorazole but in terms of metronidazole and tinidazole they agree very closely with those of Dornbusch and Nord (1974).

Summation of published data available on the activity of metronidazole against anaerobic bacteria shows that 1052 out of 1071 strains were sensitive (taking the break-point as being either 12.5 or $16 \mu \mathrm{g} / \mathrm{ml}$ ).

Poor correlation was found in the disk test between zone size and sensitivity. However, since all the strains tested here may be regarded as sensitive, criteria allowing precise interpretation cannot be stated. We suggest an MIC of $16 \mu \mathrm{g} / \mathrm{ml}$ as the breakpoint, since this value should be obtainable systemically after a $1 \mathrm{~g}$ dose of any of these three compounds. If this value is accepted, strains giving a zone size greater than $13 \mathrm{~mm}$ for metronidazole, $7 \mathrm{~mm}$ for nimorazole, and $15 \mathrm{~mm}$ for tinidazole can be considered as sensitive.

Three groups of compounds containing a primary nitro group among other features have now been shown to possess good activity against anaerobic bacteria, chloramphenicol, nitroimidazoles, and nitrofurans. The possession of such a group may be the determining factor in such activity, and it will be of interest to test this hypothesis with further compounds.

The nitroimidazoles are at present available only as oral preparations, which may be a disadvantage if the treatment of critically ill patients is contemplated. In view of the fact that metronidazole has been used successfully on a small scale for the treatment of systemic bacterial infections, the superior pharmacokinetics (Welling and Monro, 1972; de Carneri, 1969) of the two other related compounds allied to their equivalent antimicrobial activity make clinical studies of tinidazole and nimorazole mandatory.

We should like to thank Dr McFadzean, Dr Rooney, and Dr O'Neill East for the gifts of metronidazole, nimorazole, and tinidazole respectively.

Doctors S. M. Finegold and V. L. Sutter, Wadsworth VA Hospital, Los Angeles, California, H. Beerens, University of Lille, France, M. Sebald, Pasteur Institute, Paris, France, G. Lombard, Center for Disease Control, Atlanta, Georgia, R. B. Sykes, Glaxo Research, Greenford, Middlesex, B. S. Drasar, St Mary's Hospital, London, and A. Percival, University of Liverpool, kindly provided strains of Gram-negative anaerobes.

\section{References}

Davies, A. H., McFadzean, J. A., and Squires, S. (1964). Treatment of Vincent's stomatitis with metronidazole. Brit. med. J., 1, 1149-1150.

de Carneri, I. (1969). Antiprotozoan activity of nitroimidazoles. Arzneimittel Forsch., 19, 382-386.

de Carneri, I., Cantone, A., Emaneuli, A., Giraldi, P. N., Logemann, W., Meinardi, G., Monti, G., Nannini, G., Tosolini, G., and Vita, G. (1969). Nitrimidazine: a new systemic trichomonacide. 6th International Congress of Chemotherapy, Tokyo (Kyoto).

Dornbusch, K. and Nord, C. E. (1974). In vitro effect of metronidazole and tinidazole on anaerobic bacteria. Med. microbiol. Immunol., 160, 265-267.

Edwards, D. I., Dye, M., and Carne, H. (1973). The selective toxicity of antimicrobial nitroheterocyclic drugs. J. gen. Microbiol., 76, 135-145.

Ericsson, H. M. and Sherris, J. C. (1971). Antibiotic sensitivity testing. Report of an international collaborative study. Acta. path. microbiol. scand. Section B., Suppl. no. 217.

Finegold, S. M., Harada, N. E., and Miller, L. G. (1967). Antibiotic susceptibility patterns as aids in classification and characterization of gram-negative anaerobic bacilli. J. Bact., 94, 1443-1450.

Finegold, S. M. and Sutter, V. L. (1972). Antimicrobial susceptibility of anaerobic Gram-negative bacilli. In Host Resistance to Commensal Bacteria, edited by $\mathrm{T}$. MacPhee. Churchill Livingstone, Edinburgh.

Füzi, M. and Csukás, Z. (1969a). A metronidazol egy eddig ismeretlen antibacterialis hatasa. Orv. Hetil., 110, 16051606.

Füzi, M. and Csukás, Z. (1969b). A szájflóra mikroorganiz- 
musainak metronidazol érzékenysége. Orv. Hetil., 110 , 2154:2155.

Füzi, M. and Csukás, Z. (1969c). Veillonella-törzsek metronidazol-érzékenysége. Fogorv. Szle., 62, 324-326.

Füzi, M. and Csukás, Z. (1970). Das antibacterielle Wirkungs-spektrum des Metronidazols. Zbl. Bakt. I. Abt. Orig., 213, 258-262.

Györik, W. and Wenner, R. (1971). Therapie der Trichomonaden-infektion mit Tinidazol im Vergleich zu Metronidazol. Schweiz. Rundschau. Med. (PRAXIS), 60, 1612-1614.

Hamilton-Miller, J. M. T. (1975). Antimicrobial agents active against anaerobes. $J$. antimicrob. Chemother., 1 (in press).

Howes, H. L. Jr., Lynch, J. E., and Kivlin, J. L. (1970). Tinidazole, a new antiprotozoal agent: effect on Trichomonas and other protozoa. Antimicrobial Agents and Chemotherapy-1969, 8, 261-266.

Lozdan, J., Sheiham, A., Pearlman, B. A., Keiser, B., Rachanis, C. C., and Meyer, R. (1971). The use of nitrimidazine in the treatment of acute ulcerative gingivitis. A double-blind controlled trial. Brit. dent. J., 130, 294-296.

Mitchell, A. A. B. (1973). Incidence and isolation of Bacteroides species from clinical material and their sensitivity to antibiotics. J. clin. Path., 26, 738-741.

Nastro, L. J. and Finegold, S. M. (1972). Bactericidal activity of five antimicrobial agents against Bacteroides fragilis. J. infect. Dis., 126, 104-107.

Phillips, I. (1974). Antibiotic sensitivity of non-sporing anaerobes. In Infections with Non-Sporing Anaerobic Bacteria, edited by I. Phillips, and M. Sussman. Churchill, Livingstone, Edinburgh.

Prince, H. M., Grunberg, E., Titsworth, E., and deLorenzo, W. F. (1969). Effects of 1-(2-nitro-1-imidazolyl)-3-methoxy -2-propanol and 2-methyl-5-nitroimidazole-1-ethanol against anaerobic and aerobic bacteria and protozoa. Appl. Microbiol., 18, 728-730.

Reynolds, A. V., Hamilton-Miller, J. M. T., and Brumfitt, W. (1974). Newer aminoglycosides-amikacin and tobramycin: an in-vitro comparison with kanamycin and gentamicin. Brit. med. J., 3, 778-780.
Rognoni, V. and Sideri, L. (1969). Treatment of vaginitis with particular reference to those forms due to a protozoan causative factor. Clinical results with a new nitroimidazole preparation. Riv. Ostet. Ginec., 51, 237-246.

Shinn, D. L. S. (1962). Metronidazole in acute ulcerative gingivitis. Lancet, 1, 1191.

Shinn, D. L. S., Squires, S., and McFadzean, J. A. (1965). The treatment of Vincent's disease with metronidazole. Dent. Practit. dent. Rec., 15, 275-280.

Staneck, J. L. and Washington, J. A. II. (1974). Antimicrobial susceptibilities of anaerobic bacteria: recent clinical isolates. Antimicrob. Agents Chemother., 6, 311315.

Study Group (1974). Metronidazole in the prevention and treatment of bacteroides infections in gynaecological patients. Lancet, 2, 1540-1543.

Tally, F. P., Armfield, A. Y., Dowell, V. R., Jr., Kwok, Y-Y., Sutter, V. L., and Finegold, S. M. (1974). Susceptibility of Clostridium ramosum to antimicrobial agents. Antimicrob. ? Agents Chemother., 5, 589-593.

Tally, F. P., Sutter, V. L., and Finegold, S. M. (1972). Metronidazole versus anaerobes. In vitro data and initial clinical observations. Calif. Med., 117, no. 6, 22-26.

Ueno, K., Ninomiya, K., and Suzuki, S. (1971). Anti- O bacterial activity of metronidazole against anaerobic bacteria. Chemotherapy (Japan), 19, 111-114.

Videau, D. (1971). Association métronidazole-spiramycin sur les germes anaérobes. Path. Biol., 19, 661-666.

Washington, J. A., II, Martin, W. J., and Hermans, P. E. (1974). In vitro susceptibility of anaerobic bacteria isolated from blood cultures. In Anaerobic Bacteria: Role in $\vartheta$ Disease, p. 427, edited by A. Balows, R. M. Dehaar or V. R. Dowell, Jr., and L. B. Guze. Thomas, Springfiel Illinois.

Welling P. G. and Monro, A. M. (1972). The pharmacos kinetics of metronidazole and tinidazole in man. Arzneïmittel-Forsch., 22, 2128-2132.

Whelan, J. P. F. and Hale, J. H. (1973). Bactericidal activity of metronidazole against Bacteroides fragilis. J. clin. Path. 26, 393-395. 